\title{
創傷被覆材としてのサクランハイドロゲルの有効利用
}

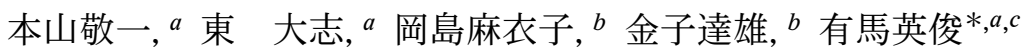

\section{Potential Use of Sacran Hydrogels as Wound Dressing Material}

\author{
Keiichi Motoyama, ${ }^{a}$ Taishi Higashi, ${ }^{a}$ Maiko K. Okajima, ${ }^{b}$ Tatsuo Kaneko, ${ }^{b}$ and Hidetoshi Arima ${ }^{*, a, c}$ \\ ${ }^{a}$ Department of Physical Pharmaceutics, Graduate School of Pharmaceutical Sciences, Kumamoto University; \\ 5-1 Oe-honmachi, Chuo-ku, Kumamoto 862-0973, Japan: bJapan Advanced Institute of Science and Technology \\ (JAIST) ; 1-1 Asahidai, Nomi, Ishikawa 923-1292, Japan: and 'Program for Leading Graduate Schools \\ "HIGO (Health Life Science: Interdisciplinary and Glocal Oriented) Program”, Kumamoto \\ University; 5-1 Oe-honmachi, Chuo-ku, Kumamoto 862-0973, Japan.
}

(Received August 27, 2017)

\begin{abstract}
A wound dressing is one of the essential approaches to prevent further harm to cutaneous wounds as well as to promote wound healing. Therefore, to achieve ideal wound healing, the development of advanced dressing materials is necessary. Sacran, a novel megamolecular polysaccharide derived from the cyanobacterium Aphanothece sacrum, has a very high molecular weight that exceeds $10^{7} \mathrm{~g} / \mathrm{mol}$ and water-superabsorbent capacity. Recently, we demonstrated that sacran exerts anti-inflammatory activity by ameliorating the skin barrier function in patients with atopic dermatitis. In this study, to develop and characterize sacran hydrogel films (Sac-HGFs) for wound dressing materials, we prepared a physically crosslinked-Sac-HGFs, and evaluated their physicochemical properties, cytotoxicity, skin hydration and wound healing ability. Additionally, we encapsulated curcumin, as a model drug for wound healing, into Sac-HGFs by complexation with 2-hydroxypropyl- $\gamma$-cyclodextrin $(\mathrm{HP}-\gamma-\mathrm{CyD})$, and investigated their potential for wound dressing application. Sac-HGF has potentially good properties for wound dressing application, due to not only the moisturizing effect but also the anti-inflammatory effect of sacran. Additionally, Sac-HGF has the potential to deliver water soluble complex of curcumin/HP- $\gamma$-CyD at the wound site and thereby promote wound healing. These findings may be useful information for preparation of wound dressing materials using sacran, CyDs and drugs.
\end{abstract}

Key words_ — sacran; hydrogel film; wound dressing; wound healing; curcumin; cyclodextrin

\section{1.はじめに}

近年，皮膚創傷に対して，(1)消毒をしない，(2)乾 かさない, (3)水道水でよく洗うという 3 原則を基に 行う治療法が普及している. かつて, 創傷は乾燥さ せれば治る，また消毒すれば細菌感染が防げると いつた認識が広がっていた。しかし，創傷の治療は 湿潤を保つ方が治癒は速く，また消毒液によつて細 菌だけでなく，創傷部の細胞も殺してしまうことか ら，近年では創傷部位を保湿する湿潤療法が主流で

\footnotetext{
$a$ 熊本大学大学院生命科学研究部製剂設計学分野 ( (862-0973 熊本市中央区大江本町 5-1), ${ }^{b}$ 北陸先端 科学技術大学院大学マテリアルサイエンス研究科 （テ923-1292 石川県能美市旭台 1-1), c熊本大学リーデ イング大学院 HIGO プログラム（†862-0973 熊本市 中央区大江本町 5-1)

*e-mail: arimah@gpo.kumamoto-u.ac.jp 本総説は, 日本薬学会第 137 年会シンポジウムS16 で 発表した内容を中心に記述したものである.
}

ある．皮膚を簡便に湿潤させる方法として，創傷部 をラップで覆うラップ療法がある. しかしながら, この方法は創傷部を完全に閉塞することができず, 重篤な感染症や治癒の遅延が起こつた症例が報告さ れている。そこで，ハイドロゲルやポリウレタン フィルム, ハイドロコロイド, ハイドロポリマーな ど，ドレッシング材と呼ばれる創傷部の被覆材が用 いられている. ドレッシング材に求められる性質と しては，ゲルやフィルムを形成できること，保水力 が高いこと, 生体適合性に優れること, 生分解性を 有することなどがあり，現在アルギン酸ナトリウム という多糖を用いたハイドロゲルなどが利用されて (る. ${ }^{1)}$

一方，硫酸化多糖体が抗炎症作用などの様々な生 理活性を有することが多数報告されている. ${ }^{2,3)}$ 代表 的な硫酸化多糖には，ヒアルロン酸，コンドロイチ ン硫酸やデルマタン硫酸などが知られている。例え 


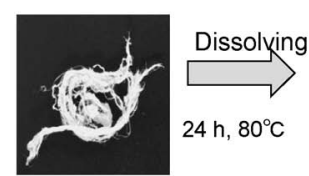

Sacran

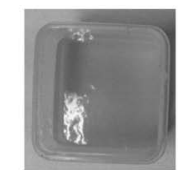

Sacran solution $(0.5 \%(\mathrm{w} / \mathrm{v}))$
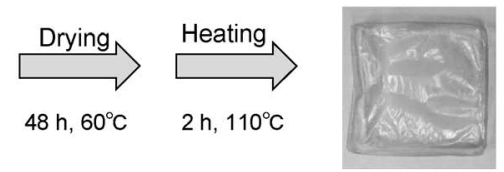

Sac-HGF

Fig. 1. Preparation of Sacran-hydrogel Film (Sac-HGF)

ば，ヒアルロン酸は，変形性膝関節症，関節リウマ チやシェーグレン症候群などの炎症性疾患に対して 用いられている。 また，コンドロイチン硫酸やデル マタン硫酸も変形性関節炎に対して抗炎症効果を有 することが知られている.

サクランは, 日本固有の食用藍藻であるスイゼン ジノリ（学名：Aphanothece sacrum）から抽出さ れた，平均分子量 1000 万以上，分子鎖長 $10 \mu \mathrm{m}$ 以 上の超高分子多糖体である. ${ }^{4)}$ サクランの特徵とし て構成糖に硫酸化ムラミン酸を有する硫酸化多糖体 であること，自重の 6100 倍の水を吸収でき，代表 的な保湿剂であるヒアルロン酸よりも5 倍以上の保 水力を有すること, さらに, ゲル形成能やフィルム 形成能があること，などが挙げられる。近年では， サクランには抗炎症効果があり，アトピー性皮膚炎 の炎症症状を緩和することが示唆されている. ${ }^{5-8)}$ 既に香粧品への応用も拡がっており, サクランの皮 膚に対する機能性が明らかになりつつある。そこで 本研究では, サクランが創傷面を被覆するドレッシ ング材として有用であるか否かを検討した. ${ }^{9-11)}$ 以 下に, 得られた知見を概説する.

2. 皮膚創傷モデルに対するサクランハイドロゲ ルフィルムの抗炎症効果

前述したように, サクランはゲル形成能やフィル ム形成能を有しており, 保水力はヒアルロン酸の 5 倍以上と非常に優れている。ささらに，食用藍藻由来 の多糖であることから生体適合性が高いものと考え られる。そこでわれわれは, サクランのドレッシン グ材としての可能性を検討した。 サクランをハイド ロゲル化する方法として，陽イオンの金属原子で陰 イオンのサクラン分子を架橋する方法と, 架橋剤を 用いずにサクラン水溶液を高温で乾燥させてフィル ム化させた後に水分を与える方法が挙げられる. ${ }^{12)}$ 後者のゲルは，金属イオンを用いないことから前者 のゲルと比較してより生体適合性に優れることが予 想される。そこでわれわれは，サクランをフィルム

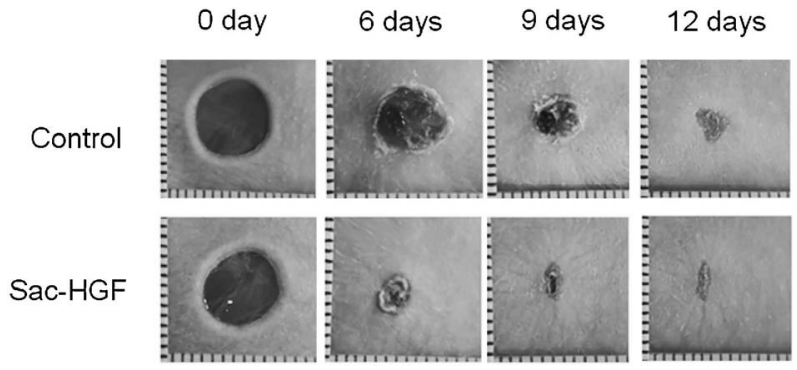

Fig. 2. Wound Healing Ability of Sac-HGF in Mice

化した後者のゲル（サクランハイドロゲルフィル ム；Sac-HGF，Fig. 1）を用いて皮膚創傷モデルに 対する治癒促進効果を検討した. ${ }^{9)}$

創傷面に湿潤環境を提供することは，創傷治癒に おいて極めて重要である。そこで，Sac-HGF をへ アレスマウスの皮膚に貼付後の皮膚水分量をモイス チャーチェッカー（MY-808S）を用いて測定した.

その結果, Sac-HGF は塗布後 1 時間でマウスの皮 膚水分量を未処理群よりも約 2 倍上昇させることが 示唆され，その効果は少なくとも 12 時間は持続し た. 9)これらの結果より，Sac-HGF を皮膚に貼付す ることにより，湿潤環境を提供可能であることが示 唆された。

さらに, Sac-HGF の創傷治癒促進効果につい て，ヘアレスマウスを用いて検討した。実験は，生 検パンチを用いてマウスの背部皮膚に一定サイズの 創傷を形成させた後, Sac-HGF を貼付して, 創傷 部の面積を経時的に測定した。その結果, SacHGF を貼付したマウスの創傷面積は, 何も貼付し ていない場合と比較して小さく, 治癒速度が速いこ とが示唆された（Fig. 2)。これらの結果より，SacHGF は創傷部の湿潤環境を保つことで，治癒を促 進したものと考えられる。 また，これまでの検討か ら，サクランは皮膚において抗炎症効果を示すた め，創傷部における過度の炎症を抑制することも治 癒促進に関与しているものと推察される. ${ }^{9)}$ 


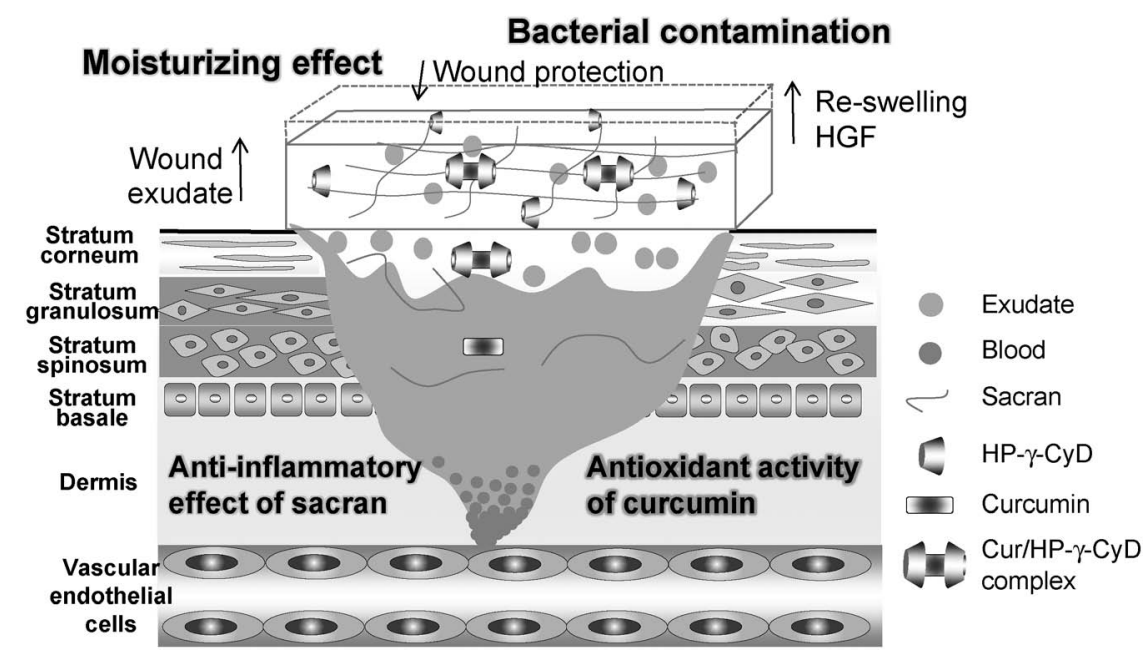

Fig. 3. Proposed Wound Healing Ability of Sac-HGF Containing Curcumin/HP- $\gamma$-CyD Complex

3. 皮膚創傷モデルに対するクルクミン/HP- $\gamma$ CyD 複合体含有 Sac-HGF の抗炎症効果

クルクミンはカレーのスパイスでもあるターメ リックの黄色色素で, ポリフェノールの一種であ る. 生理作用として抗腫瘍作用や抗酸化作用, 抗ア ミロイド作用，抗炎症作用，創傷治癒促進作用など が知られている．しかしながら，クルクミンは溶解 度が低いため, 皮膚に塗布しても十分な効果が得ら れない，一方，環状オリゴ糖であるシクロデキスト リン (cyclodextrin; CyD) は，分子内の疎水性空洞 に薬物を取り込み，包接複合体を形成することによ り薬物の溶解性を改善することから，医薬分野にお いて可溶化剤として汎用されている，中でも，ヒド ロキシプロピル- $\gamma$-シクロデキストリン $(\mathrm{HP}-\gamma-\mathrm{CyD})$ はクルクミンを効率よく可溶化することが報告され ている. ${ }^{13)}$ そこでわれわれは，クルクミン/HP- $\gamma$ CyD 複合体を Sac-HGF に封入させることにより， 協調的な創傷治癒促進効果を示す HGF を構築し た. ${ }^{10)}$

クルクミン/HP- $\gamma$-CyD 複合体は, キャスティン グ法により Sac-HGF に均一に封入可能であつ た. ${ }^{10)}$ 一方，クルクミン単独及びクルクミンと HP$\gamma$-CyD の物理的混合物は, キャスティング後, ク ルクミンが析出したために, Sac-HGF に均一に封 入させることは困難であった。 また，クルクミン/ HP- $\gamma$-CyD 複合体封入 Sac-HGF は，クルクミン溶 液中で徐々にクルクミンを放出し，抗酸化効果を発

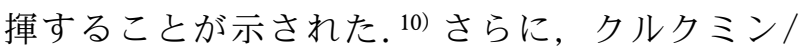
HP- $\gamma$-CyD 複合体封入 Sac-HGF は，ヘアレスマウ
スの皮膚損傷モデルに対して，クルクミン封入 Sac-HGF 及びクルクミン/HP- $\gamma-\mathrm{CyD}$ 物理的混合物 封入 Sac-HGF よりも優れた創傷治癒促進効果を有

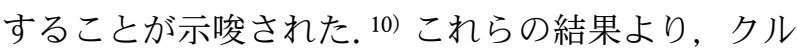
クミン/HP- $\gamma-\mathrm{CyD}$ 複合体封入 Sac-HGF は，創傷部 位を被覆することにより，(1)細菌感染の防御，(2)湿 潤環境の維持, (3)サクラン自体の抗炎症効果, (4)ク ルクミンの抗炎症・抗酸化効果，などにより創傷治 癒を促進したものと考えられる（Fig. 3).

4. おわりに

サクランには, 日本固有の藍藻スイゼンジノリが 秘めた驚異的な機能があり，その特性には魅了され るばかりである。本稿では，サクランをドレッシン グ材に応用し，その創傷治癒促進効果を中心に概説 した，誌面の都合上，記載しなかつたが，われわれ の研究室ではサクランの製剂素材としての有用性評 価や再生医療への応用に関する研究も行っている. 今後もサクランの医薬への応用に関する研究を通じ て，世界の健康医療に貢献したい。

謝辞サクランをご提供頂いたグリーンサイエ ンス・マテリアル株式会社に御礼の意を表します。

利益相反 有馬英俊（株式会社 CyDing の役 員，グリーンサイエンス・マテリアル株式会社との 共同研究を実施).

\section{REFERENCES}

1) Shojaee M., Navaee F., Jalili-Firoozinezhad 
S., Faturechi R., Majidi M., Bonakdar S., Mater. Sci. Eng. C Mater. Biol. Appl., 48, 158-164 (2015).

2) Hoare T. R., Kohane D. S., Polymer, 49, 1993-2007 (2008).

3) Zhao W., Jin X., Cong Y., Liu Y., Fu J., J. Chem. Technol. Biotechnol., 88, 327-339 (2013).

4) Okajima M. K., Bamba T., Kaneso Y., Hirata K., Fukusaki E., Kajiyama S., Kaneko T., Macromolecules, 41, 4061-4064 (2008).

5) Fukushima S., Motoyama K., Tanida Y., Higashi T., Ishitsuka Y., Kondo Y., Irie T., Tanaka T., Ihn H., Arima H., J. Cosm. Derm. Sci. Appl., 6, 9-18 (2016).

6) Motoyama K., Tanida Y., Hata K., Hayashi T., Abu Hashim I. I., Higashi T., Ishitsuka Y., Kondo Y., Irie T., Kaneko S., Arima H., Biol. Pharm. Bull., 39, 1172-1178 (2016) .

7) Motoyama K., Tanida Y., Hata K., Hayashi T., Higashi T., Ishitsuka Y., Kondo Y., Irie T., Kaneko S., Arima H., Chem. Pharm.
Bull., 62, 636-641 (2014).

8) Ngatu N. R., Okajima M. K., Yokogawa M., Hirota R., Eitoku M., Muzembo B. A., Dumavibhat N., Takaishi M., Sano S., Kaneko T., Tanaka T., Nakamura H., Suganuma N., Ann. Allergy Asthma Immunol., 108, 117-122 (2012).

9) Wathoni N., Motoyama K., Higashi T., Okajima M., Kaneko T., Arima H., Int. J. Biol. Macromol., 89, 465-470 (2016).

10) Wathoni N., Motoyama K., Higashi T., Okajima M., Kaneko T., Arima H., Int. J. Biol. Macromol., 98, 268-276 (2017).

11) Wathoni N., Motoyama K., Higashi T., Okajima M., Kaneko T., Arima H., Int. J. Biol. Macromol., 94, 181-186 (2017) .

12) Okajima M. K., Mishima R., Amornwachirabodee K., Mitsumata T., Okeyoshi K., Kaneko T., RSC Adv., 5, 86723-86729 (2015) .

13) Tønnesen H. H., Másson M., Loftsson T., Int. J. Pharm., 244, 127-135 (2002). 